\title{
POLITICAL, LEGAL AND INSTITUTIONAL ASPECTS OF THE POLICY OF THE MANAGEMENT OF DIASPORA IN THE REPUBLIC OF MOLDOVA ${ }^{1}$
}

\author{
Tatiana Turco, ${ }^{2}$ Rodica Svetlicinai ${ }^{3}$
}

\begin{abstract}
The article is devoted to the study of political, legal and institutional aspects of the policy of diaspora management in the Republic of Moldova. The authors consider that the Moldovan authorities are trying to develop a coherent state policy on the Diaspora through an integrated approach. This is reflected in the legislative and institutional framework of the state policy in the field of Diaspora. As the results of sociological research, Moldovan migrants do not actively participate in the activity of Diaspora organizations. The authors note that in order to develop an effective management policy Diaspora in the Republic of Moldova, the creation of institutions is necessary to ensure the preservation and development of the Diaspora; development of a strategy of interaction with state institutions as the country of residence, and the "title" of the state; development of legal acts on the Diaspora, as well as laws and policies on management of the diaspora processes. These measures will provide creation and strengthening of a stable platform for cooperation between the state and the Moldovan diaspora, the active participation of the diaspora in the economic and political life of the Republic of Moldova.
\end{abstract}

KEY WORDS: Moldovan diaspora, Diaspora management policies, legal framework, state institutions, Diaspora organizations.

\section{INTRODUCTION}

Migration is a megatrend of the 21st century. According to the United Nations, there are 232 million international migrants in the world today

\footnotetext{
${ }^{1}$ The article was written as a part of institutional project no. 15.817.06.21F, „Moldovan diaspora policies in the context of the Association Agreement with the European Union: strengthening the role of diasporas in development of the state of origin".

${ }^{2}$ Associate professor, Ph.D. (Political Science), Faculty of International Relations, Political and Administrative Sciences, Moldova State University, Chisinau, Republic of Moldova, E-mail: turcotatiana27@gmail.com

${ }^{3}$ Associate professor, Ph.D. (Historical Science), Faculty of International Relations, Political and Administrative Sciences, Moldova State University, Chisinau, Republic of Moldova, E-mail: svetliciniirodica@yahoo.com
} 
(Global Diaspora and Development Forum, 2014). Moldova is in the top 10 countries in terms of migration to other countries. The 2018 estimated population of Moldova is 3.54 million (Anuarul, 2018, p.37.) and the number of Moldovan migrants is about 1 million. Most of the Moldovan migrants are in Russia - 478 thousand people and countries of the European Union 259 thousand people, as well as in Ukraine, the United States and Canada. (Численность... , 2017).

The unprecedented growth of migration flows leads to the formation of numerous diasporas, which differ in size, geographical location, socioeconomic characteristics and ties with the motherland. This poses a challenge for states to effectively manage the diasporas as a potential extension of the state of origin beyond its borders.

In the broad sense, the term "diaspora" means emigrants and their descendants who live outside the country of their birth or their ancestors on a temporary or permanent basis, but at the same time retain spiritual and material ties with their country of origin. However, more recently this term has been increasingly used to refer to ethnic groups that have emerged as a result of labor migration, which are defined as "new" diasporas. The common between newly arrived migrants and members of long-established communities is that they identify themselves with their country of origin or their ancestors and are ready to keep in touch with it (Agunias, Newland, 2012 , p.15). We consider that the diaspora is a group of ethnic minorities of migration origin, which carry out collective activities to preserve ties with their homeland, to consolidate their ethnic community in the host country.

In recent decades, the interest in the problem of diaspora management has been growing in the political and scientific environment. (Spiro, 2006; Brinkerhoff, 2012; Milonas, 2013). As the analysis of national and foreign scientific sources has shown, the problem of diaspora management is considered as part of the migration policy and has been studied fragmentarily. At the international forums on migration and the diaspora, this topic is also given very little attention, meanwhile it is becoming increasingly important (Délano, Gamlen, 2015). Therefore, management activities related to the implementation of public policy in relation to the foreign diaspora require comprehensive scientific research.

The Moldovan diaspora is one of the "new" diasporas. In such countries as Russia, Italy, Spain, Portugal and other communities of Moldovan citizens are formed in the process of their labor migration. In this context, we should mention the studies by R. Shwartz (Israel) and T. Kring (Germany). (Schwartz, 2007; Kring, 2007). In Moldavian science, the diaspora has 
been the subject of research since the early 2000s. Mentioning the work of D. Cheanu-Andrei, V. Mukomel and V. Mosneaga on the mapping of the Moldovan diaspora (Cheianu-Andrei, 2013; Mukomel, Cheianu-Andrei, 2013; Mosneaga, 2017). V. Mosneaga considers various aspects of the formation of the Moldovan diaspora and migration policy of the Republic of Moldova (Mosneaga, 2013; Mosneaga, 2014). In the framework of the institutional project 15.817.06.21F "Moldovan Diaspora Policies in the Context of the Association Agreement with the European Union: Strengthening the Role of Diasporas in development of the State of Origin" the researches of the phenomenon of the diaspora are engaged by the staff of the "Sociology of Politics" laboratory at the Moldavian State University.

The purpose of this article is to analyze the political, legal and institutional aspects of the interaction of the government and the diaspora in the Republic of Moldova. To achieve this goal, in firstly we will analyze the activities of the state institutions of the Republic of Moldova in the implementation of the policy of diaspora management; secondly we will represent the architecture of the Moldovan diaspora organizations. Based on a sociological survey conducted among Moldovan migrants we will research the activity of diaspora organizations in host countries.

The sociological survey was carried out in 2016-2017 with the participation of the authors. Quantitative research was done both in the country of origin (the Republic of Moldova) and in six countries of destination of Moldovan migrants (The United Kingdom, Germany, Israel, Italy, Portugal, and Russia). The main survey method was a standardized face-to-face interview. In total, 538 respondents were interviewed.

This choice was due to a certain country specificity, which allowed to obtain a more complete image of formation of Moldovan communities and the diaspora abroad. Russia is the main consumer of Moldovan labor migrants. The common historical fate, preservation of a single visa-free area after the collapse of the Soviet Union, knowledge of the Russian language, mentality, culture, the same faith have contributed to the growth of labor migration to Russia during the economic crisis.

In the European Union Italy is the main consumer of Moldovan labor migrants. According to official data of the Ministry of Labor of Italy for 2016, there were more than 150,000 Moldovan citizens who have a residence permit in the country. In fact, there are significantly more of them, as many of them are either illegally or on the basis of Romanian, Bulgarian passports or passports of other EU countries. (Mosneaga, 2017, p.49-50). 
Portugal was one of the first countries to which Moldovan migrant workers traveled. In 2015, there were officially registered 6.948 Moldovan citizens (Extended, 2017b, p.117). The affinity between the Romanian and Italian as well as Romanian and Portuguese languages contributed and facilitated the process of Moldovan citizens' integration into Italian and Portuguese societies. Besides, both countries have many years of experience of tolerant and open attitude towards immigrants.

A significant Moldovan-Jewish diaspora was formed since the Soviet era in Israel. It often plays the role of social networks for the current Moldovan labor migrants. At the end of 2017, there were 13,000 Moldovan citizens in Israel.

Germany has a powerful economic potential, a huge labor market, and a developed social system. Germany as a country of labor migration for Moldovans is only opening. This is explained by the fact that Germany opens its labor market for Romanian citizens (a significant number of Moldovans use Romanian passports for entry and work in the EU countries) only since the early 2010s. In 2015, there were about 14,815 Moldovan citizens in Germany (Extended, 2017b, p.117).

The interest in the plans and strategies of Moldovan labor migrants in the UK arose in the context of Brexit. The study is of interest because it reflects the psychological state, moods, and plans of Moldovan citizens who are in the UK and face certain risks and fears. According to the estimates of the consulate and the statistics of the UK, the number of Moldovan citizens in the United Kingdom of Great Britain and Northern Ireland is approaching 30 thousand people (Mosneaga, 2017, p.60).

\section{ACTIVITY OF THE STATE INSTITUTIONS OF THE REPUBLIC OF MOLDOVA IN THE IMPLEMENTATION OF THE POLICY OF DIASPORA MANAGEMENT}

In recent years, the state authorities of the Republic of Moldova have recognized the importance of the diaspora, which can make a significant contribution to the economic and social development of the country, contribute to the promotion of the international image of the Republic of Moldova. Therefore, the state stepped up its activities in this direction, defining measures and instruments of state policy on diaspora management.

Researchers distinguish five roles in which the state manifests itself in relation to its citizens living abroad: representational, intermediary, donor (funding), partnership and support (Brinkerhoff, 2012, pp.75-95). 
The representative role presupposes the existence of a legal and regulatory framework for the diaspora and regulates such issues as citizenship, the right to establish non-governmental organizations or to engage in entrepreneurial activities. In addition, access to public information, transparency in the decision-making process allows diaspora representatives to familiarize themselves with state programs and policies and participate in the process of communication with state institutions.

Analyzing the representative role of the Moldovan state in relation to migrants, we note that in recent years a number of strategic documents have been adopted aimed at expanding cooperation between the government of the Republic of Moldova, local and central authorities, civil society and the Moldovan diaspora.

Beginning in the early 2000s, a set of normative acts reflecting the basic principles and forms of support for immigrants from Moldova was adopted. Among them we can mention: the President of the Republic of Moldova Decree on support and cooperation with immigrants from the Republic of Moldova living abroad (2000); Decree of the Government of the Republic of Moldova on the Coordinating Council of Immigrants from the Republic of Moldova Living Abroad (2005). The Program of Government Activities for 2015-2018 included for the first time a special chapter on cooperation with the Diaspora, which set out priority areas in this area (15 priority, 2015). The "Diaspora-2025" strategy has become an important document defining the policy of the authorities towards the Diaspora in the next decade (Hotărîrea, 2016).

As an intermediary, the state promotes and supports its citizens abroad. This is expressed in negotiations with the governments of those countries where Moldovan citizens are located, in particular, about the expansion of their rights in the host country (right to reside, to work, etc.). The Office for Diaspora Relations (ODR), established in November 2012, is a specialized agency of the Republic of Moldova to support and cooperate with the Moldovan diaspora. In addition, in order to implement a comprehensive and integrated approach ("the whole-of-the-Government") in the development of diaspora policy in ministries, persons responsible for the development of policies for and with the participation of the Moldovan diaspora were appointed.

In this context, it should be noted the program "The Government is closer to you", developed by the ODR, which provides for the organization of working visits to countries with a large number of immigrants from Moldova. Thanks to this program, ODR provides an opportunity for ministries to 
inform citizens abroad about their activities to promote new projects and services for the diaspora and to establish partnerships with citizens abroad.

In the role of donor, the state performs direct financing of entrepreneurial activities of diaspora members, in addition to their own contributions and investments. In addition to direct financing, financial support from governments includes the introduction of financial incentives, such as tax exemptions, that are intended to adjust tax policies and encourage diaspora contributions.

In 2010, Moldova launched a program to attract remittances to the economy "PARE $1+1$ ", intended for migrant workers who wish to invest in the opening or expansion of business in Moldova. Under this program, migrants invested about 100 million lei in the economy of the country of origin, which resulted in the opening of about 3,000 jobs (Moldovan, 2014). This figure is very small compared to the amount of remittances that Moldovan migrants send to their country of origin. Only in 2018 the volume of remittances to Moldova through banks in favor of individuals amounted to $\$ 1$ billion 266.84 million (The volume, 2018).

The Government of Moldova has announced other programs to stimulate the return migration and reintegration of migrants in their homeland: the "Action Plan for the Return of Moldovan Labor Migrants from Abroad", the National Program for the Expansion of Economic Opportunities for Youth (PNAET). In early 2016, with the financial support of the Swiss Agency for Development and Cooperation of ODR and IOM Moldova, the "Diaspora Engagement Hub" thematic grants program for Moldovan citizens residing abroad was launched. The Government of the Republic of Moldova sponsors the holding of cultural events in those countries where there are Moldovan communities. About 30 thousand people took part in these events in 40 cities of Europe, the Middle East and the USA.

The partnership between the state and the diaspora is based on mutual interest and mutual benefit. In such situations, the government initiates mechanisms and procedures that allow state structures to enter into a trusting partnership with diaspora organizations. Members of migrant communities are directly involved in the formation of public policies and initiate their own development projects. Holding Days of Diaspora and Diaspora Congresses is becoming a tradition, which serves as a platform for discussions and meetings between the government and representatives of the diaspora, encourages the launch of new initiatives and projects. The Eighth Congress of the Moldovan Diaspora, which was attended by compatriots from 20 countries, took place in Chisinau in August 17-18, 2018. 
The role of support is manifested in the fact that the state protects Moldovan citizens living abroad. In addition, support can be expressed in rewarding representatives of the diaspora with state awards and government diplomas for special services in promoting the culture and image of the country abroad, preserving national traditions and culture.

Within the framework of the Global Forum on Migration and Development, the International Organization for Migration and the Institute for Migration Policy developed a "roadmap" aimed at involving diasporas in the development process (Agunias, Newland, 2012). Undoubtedly, the relations of each diaspora with the country of origin and countries of destination are unique in their own way, but the fundamental elements are necessary components of almost all successful strategies for engaging the diaspora.

The strategy to promote the effective involvement of the diaspora in the development process consists of successive steps. The first step in developing the strategy is the government's ability to determine its goals and the available potential (administrative, financial, etc.) necessary to accomplish this task. Moldova's goal is to reduce poverty and maintain the national balance of payments, therefore, the country's policy towards its diaspora should focus, first of all, on reducing the cost of remittances, developing investment tools and financial services. In addition, a dialogue between the governments of countries of origin and destination, as well as between the government and members of the diaspora, is needed to determine realistic and forward-looking goals.

The government of the country of origin should learn about its diaspora as much as possible. An important step in this direction is the full-scale comprehensive data collection, for example, by conducting a migrant / diaspora census; cartography of the diaspora, etc.

The Republic of Moldova does not have comprehensive data on its diaspora, but is actively working in this direction. The first sources of cartography of the Moldovan diaspora are studies of the socio-economic profile of Moldovan citizens temporarily or permanently residing in the Russian Federation and in a number of EU countries (Cheianu-Andrei, 2013; Mukomel, Cheianu-Andrei, 2013). A study carried out with the support of IOM in six countries - Germany, Great Britain, Israel, Italy, Portugal and Russia - contributed to obtaining extensive information about the Moldovan diaspora (Mosneaga, 2017). An important tool to improve existing methods of collecting migration data is the "Extended Migration Profile of the Republic of Moldova", developed at the initiative of the IOM (Extended, 
2014; Extended, 2016; Extended, 2017a; Extended, 2017b). In March 2013, with the support of the Austrian non-governmental organization Hilfswerk, a digital map of the diaspora diaspora.md was launched, which shows the location of embassies and missions, consulates and consular departments of the Republic of Moldova, as well as public associations of the Moldovan diaspora abroad.

The third necessary element of the strategy of interaction with the diaspora is the strengthening of trust between the government and the diaspora. For the governments of the countries of origin, building trust with the diaspora involves creating an enabling environment for diaspora participation in development activities, in particular the creation of a favorable climate in the country of origin to attract investment and organize business. To this end, in 2015, a business forum of representatives of the Moldovan diaspora was held.

The realization of their political rights is of great importance for representatives of diasporas. Governments can demonstrate trust by promoting voting and other forms of political participation of emigrants abroad. In order to ensure the constitutional right of Moldovan citizens residing outside the country, the Moldovan authorities open polling stations abroad. However, they are very selective in addressing this problem, which is connected with the division of the Moldovan population and the Moldovan diaspora according to the geopolitical sign (Turco, Svetlichnai, 2015, p.229). As a rule, representatives of the diaspora in Russia vote for political parties that advocate cooperation with Russia and the Eurasian Economic Union. Moldovan citizens who are in European countries, the United States and Canada vote for parties that support cooperation with the EU and the Western vector of development of the country.

The Moldovan government is interested in awakening the interest of young people of the second and third generation of migrants to their cultural identity. To this end, since 2013, the program "DOR" ("Diaspora, origin, roots"), for children and teenagers from the diaspora, whose purpose is to create an emotional connection between the representatives of the Moldovan diaspora and their country of origin.

Establishing trust between governments and diasporas leads to the next step - mobilizing diasporas for development. This requires the interaction of all stakeholders - governments, consular institutions, the diaspora, civil society. It should be noted that the potential of Moldovan diplomatic missions abroad is used in an inefficient way. Moldovan citizens turn to these missions, as a rule, when they have problems with documents that can 
be solved only through these institutions. This is confirmed by the data of a sociological poll - 2/3 of migrants do not apply to Moldovan state structures abroad (Mosneaga, 2017, p.146). Migrants often accuse the diplomatic services of ineffectiveness of their work, corruption and unprofessional attitude towards their citizens.

The state should proceed from the fact that the diaspora is a valuable capital, therefore, an important direction should be to ensure the connection between the diaspora and the country of origin, based on trust and common initiatives.

\section{ARCHITECTURE OF THE ORGANIZATIONS OF THE MOLDOVAN DIASPORA}

Diaspora organizations, created by Moldovan citizens in the host countries, play an important role in the implementation of the diaspora management policy. These organizations aim to bring together and unite the Moldovan diaspora, effectively integrate their members into the host society, maintain a spiritual connection with their homeland. The creation of such organizations indicates the process of institutionalization of the Moldovan diaspora (Mosneaga, 2014, p.163).

According to the Office for Relations with the Diaspora of the Republic of Moldova at the end of 2016, 94 associations of the Moldovan diaspora in 19 countries of the world were registered on the basis of self-registration (Lista, 2016). They are quite diverse and vary depending on the legal status, management model, area of activity; in most cases, nationality and citizenship act as integrating factors.

In order to briefly characterize the organizations of the Moldovan diaspora in the countries where the sociological survey was conducted, the following can be noted. In the UK, there are two officially registered associations of the Moldovan diaspora - the Association of Moldovan Students in the UK and "Vatra", which carry out a variety of activities to consolidate Moldovan citizens. Diaspora organizations in the UK are characterized by high social activity, and the ability to independently seek funding for their projects.

The associations of the Moldovan diaspora in Germany are few, their activity is insignificant. This is primarily due to the lagging nature of the formation of Moldovan communities in this country (Mosneaga, 2017, p.115). Nevertheless, they conduct cultural events aimed at promotion of the positive image of Moldova and its traditions. 
In Israel there are many organizations wishing to participate in the program of cooperation with the diaspora. Unlike other countries, in Israel, associations of the Moldovan diaspora were formed by ethnic Jews, natives of Moldova, who left for their historical homeland both in Soviet times and from the independent Republic of Moldova. A positive role in consolidating the immigrants from Moldova and their adaptation to the reality of Israel was performed by Beit Bessarabia and the association of immigrants from Moldova Izvorash. Over the past few years, Beit Bessarabia has become a meeting place for Israeli businessmen who are interested in establishing economic and commercial activities in the Republic of Moldova (Anikin, 2016, pp.133-136). The activities of Izvorash are aimed at consolidating the immigrants from Moldova, preserving the traditions of Moldovan Jewry and promoting humanitarian and cultural relations between the Jewish and Moldovan societies.

Moldovan and foreign experts believe that the formation of diaspora organizations is to the greatest extent taking place in Italy (Mosneaga, 2017, p.11). Officially, more than 50 associations belonging to the Moldovan diaspora have been registered in Italy. The huge number of Moldovan diaspora organization can be explained by the large number of Moldovan migrants and the affinity of languages. But most of these organizations are poorly structured, not active, and exist only on a paper. Moldovan migrants publish the newspaper Gazeta Basarabiei, which is distributed in a printed and online form.

In Portugal, there are about 10 associations of the Moldovan diaspora, which function where there are more Moldovan citizens. These organizations strive to strengthen relations between community members through the development of mutual assistance, the organization of various events, the maintenance of a spiritual connection with the motherland. In addition, their activities are aimed at informing Moldovan migrants, development of Moldovan culture and traditions abroad. We believe that Portugal is one of the three most developed Moldovan diasporas and their associations abroad along with Italy and Canada.

In the Russian Federation there are 25 associations of Moldovans, not only in Moscow and St. Petersburg, but also in other regions of Russia (Associations, 2016). All these organizations to some extent provide legal, social, cultural and other interests of immigrants from Moldova. Given the number of Moldovan migrants in Russia, this figure is not high. This is due, firstly, to the peculiarities of Russian legislation in the field of registration of diaspora organizations, and secondly, Moldovan migrants in Russia do 
not always strive for unification. According to experts, this is due, on the one hand, to the circular nature of labor migration, the watchful attitude of migrants to diasporal organizations. On the other hand, Russia's lack of openness, its integration policy towards migrants, and the difference in approaches to representatives of various regions of Moldova (Mosneaga, 2017, p.119). Russia has a more favorable attitude towards people from Transnistria and Gagauzia (Autonomous Territorial Unit in the south of Moldova), since the authorities of these regions carry out pro-Russian policy.

Membership in diaspora associations demonstrates the migrant's desire to maintain ties with the motherland not only on an individual, but also on a collective level. The results of a sociological survey of representatives of Moldovan communities conducted in six countries showed that only $5.6 \%$ of respondents are members of any Moldovan organization in the host country.

$12.3 \%$ of respondents attributed themselves to active members of Moldovan diaspora organizations, and in Italy, Germany and Israel this figure was $0 \% .28 .8 \%$ of the respondents indicated that they sometimes participate in diasporal organization activities. To this group, $42 \%$ of respondents referred to Germany; every third in Russia; one in four in Italy, Portugal and the United Kingdom; in Israel there are no such migrants at all $(0 \%)$. The answer "I only follow the events and news of the organization, but I do not actively participate" was supported by 59\% of migrants surveyed. This indicates that the bulk of respondents who consider themselves members of the Moldovan diaspora associations are not active participants in the process.

93.9\% of respondents are not members of any Moldovan diaspora organization. In Russia and Israel, this figure is 96\%, in Germany - 94\%; 93\% in Italy; $92 \%$ in Portugal. The exception is Great Britain, where the share of respondents who are not members of Moldovan associations is significantly lower and is $82 \%$ (Mosneaga, 2017, p.136).

When asked about the reasons for non-participation in the activities of the Moldovan organizations of the Diaspora, $43 \%$ of respondents answered that they are not interested in it and $12.7 \%$ do not think that it is important. Almost every third migrant indicated that he does not know any Moldovan organizations in the region where he lives. Such a response does not exclude interest in such organizations and it can be assumed that there are potential participants among this group.

Respondents were asked to assess whether the tasks facing the Moldovan organizations in the country of their stay are unimportant / important (Table 1). The most important (the answers are "important" and "very important") 
Moldovan migrants consider the support of the Moldovan education of children (language, history, literature, etc.) - 78.6\%. This direction opens up a wide field of activity for diaspora organizations that, in cooperation with the Moldovan offices in the host countries of migrants, can open Sunday schools, various circles for studying the language, history, literature, traditions of Moldova. This, in turn, will help consolidate the Moldovan community. But, according to the survey, the consolidation of the Moldovan community is considered by the "important" and "very important" task to be the smallest number of respondents $-60.6 \%$.

Three quarters of respondents consider informing the diaspora about the situation in Moldova as an important task for Moldovan organizations in host countries. $74.9 \%$ indicated the importance of promoting the image of Moldova during cultural events at the local, national and international levels.

Almostidenticalinimportancetothetasks that theMoldovan organizations in the host countries must solve, were the support of Moldovans to organize their life in the host country (73.8\%) and the support of Moldovan relations with Moldova (73.7\%). $68.8 \%$ of respondents consider it an important task for diaspora organizations to contribute to the successful cultural and social integration of new immigrants. Moldovan migrants do not want to lose ties with their homeland - 71\% of respondents consider it important to promote the development of a "small homeland", 69.9\% note the need to participate in the development of Moldova, and $72.9 \%$ indicate the importance of carrying out charitable actions in support of socially vulnerable groups of the population.

More than two thirds of respondents consider it important to advertise famous people - representatives of the diaspora, as well as support initiatives to spread new knowledge, technologies, etc. As for the indicator "to promote respect for the rights of representatives of the diaspora," only $64.7 \%$ of respondents indicated it as "important" and "very important". Meanwhile, this indicator attests to the attitude towards migrants on the part of the host society. The least important, according to respondents, is the establishment of contacts with similar associations from other countries (63\%).

As shown by the study, Moldovan migrants do not show much activity in the activities of diaspora organizations. At the same time, they believe that the activities of these organizations are important for preserving the Moldovan culture and traditions, and for promoting the image of Moldova at the local, national and international levels. 
Table 1: Assessment of the importance of the tasks faced by Moldovan organizations in the host country, \%

\begin{tabular}{|c|c|c|c|c|c|}
\hline & $\begin{array}{c}\text { Completely } \\
\text { irrelevant }\end{array}$ & Irrelevant & $\begin{array}{c}\text { I do not } \\
\text { know }\end{array}$ & Important & $\begin{array}{c}\text { Very } \\
\text { important }\end{array}$ \\
\hline $\begin{array}{l}\text { support for } \\
\text { Moldovans to } \\
\text { organize their } \\
\text { lives in host } \\
\text { country }\end{array}$ & 1.7 & 4.1 & 20.4 & 41.8 & 32.0 \\
\hline $\begin{array}{c}\text { support } \\
\text { communica- } \\
\text { tion between } \\
\text { Moldovans and } \\
\text { Moldova }\end{array}$ & 1.5 & 5.6 & 17.3 & 43.7 & 32.0 \\
\hline $\begin{array}{l}\text { informing Mol- } \\
\text { dovans about } \\
\text { the situation in } \\
\text { Moldova }\end{array}$ & 1.1 & 5.1 & 17.5 & 44.6 & 30.5 \\
\hline $\begin{array}{l}\text { participate } \\
\text { in the deve- } \\
\text { lopment of } \\
\text { Moldova }\end{array}$ & 1.3 & 5.9 & 24.7 & 36.1 & 31.8 \\
\hline $\begin{array}{l}\text { to support the } \\
\text { Moldovan chil- } \\
\text { dren's educati- } \\
\text { on (language, } \\
\text { history, etc.) }\end{array}$ & 1.9 & 5.8 & 13.8 & 39.8 & 38.8 \\
\hline $\begin{array}{l}\text { contribute to } \\
\text { the consoli- } \\
\text { dation of the } \\
\text { Moldovan com- } \\
\text { munity }\end{array}$ & 3.5 & 5.9 & 29.7 & 41.1 & 19.5 \\
\hline $\begin{array}{l}\text { contribute to } \\
\text { the successful } \\
\text { cultural and so- } \\
\text { cial integration } \\
\text { of new immig- } \\
\text { rants }\end{array}$ & 2.0 & 5.0 & 24.0 & 43.5 & 25.3 \\
\hline
\end{tabular}




\begin{tabular}{|c|c|c|c|c|c|}
\hline $\begin{array}{l}\text { promote } \\
\text { respect for the } \\
\text { rights of the } \\
\text { Diaspora }\end{array}$ & 2.0 & 5.4 & 27.9 & 38.5 & 26.2 \\
\hline $\begin{array}{l}\text { promote the } \\
\text { image of Mol- } \\
\text { dova }\end{array}$ & 1.7 & 5.8 & 17.7 & 42.4 & 32.5 \\
\hline $\begin{array}{l}\text { to carry out } \\
\text { charitable } \\
\text { activities in } \\
\text { support of the } \\
\text { socially vulne- } \\
\text { rable }\end{array}$ & 2.0 & 3.9 & 21.0 & 40.9 & 32.0 \\
\hline $\begin{array}{l}\text { to support } \\
\text { initiatives for } \\
\text { the dissemi- } \\
\text { nation of new } \\
\text { knowledge and } \\
\text { technologies, } \\
\text { etc. }\end{array}$ & 3.2 & 6.9 & 23.2 & 42.4 & 24.3 \\
\hline $\begin{array}{c}\text { advertise } \\
\text { famous people - } \\
\text { representatives } \\
\text { of the Diaspora } \\
\text { (scientists, } \\
\text { artists, etc.) }\end{array}$ & 2.8 & 6.9 & 23.4 & 41.8 & 25.1 \\
\hline $\begin{array}{l}\text { to establish } \\
\text { contacts with } \\
\text { similar asso- } \\
\text { ciations from } \\
\text { other countries }\end{array}$ & 3.5 & 5.9 & 27.3 & 40.9 & 22.1 \\
\hline $\begin{array}{l}\text { to promote the } \\
\text { development of } \\
\text { a small country } \\
\text { (population } \\
\text { centers of ori- } \\
\text { gin) in Moldova }\end{array}$ & 1.5 & 3.7 & 23.8 & 41.8 & 29.2 \\
\hline
\end{tabular}

Source: Sociological research conducted by the authors in 2016-2017 


\section{CONCLUSION}

This article has analyzed the political, legal and institutional aspects of the management of diaspora in the Republic of Moldova. The legal framework within which the Diaspora Management Policy is implemented in the Republic of Moldova has been defined; the activities of state institutions in this direction were analyzed; the architecture of the Moldovan diaspora organizations in host countries was presented.

Assessing the impact of migration on the country's development, the Moldovan authorities are making attempts to develop and promote a coordinated policy of the state in the field of the diaspora through an integrated approach. This is reflected in the complex of the adopted normative acts, as well as in the distribution of functional duties among the core central authorities and institutions.

The architecture of the Moldovan diaspora organizations abroad is quite diverse. But, as sociological studies show, membership in diaspora organizations among Moldovan migrants is small. In our opinion, the main reason is the desire of Moldovan migrants to integrate into the host society. In addition, this is due to a lack of interest in the activities of the organizations, as well as the lack of knowledge of Moldovan organizations in the region where they live. This is an indicator, which, on the one hand, allows to judge the moods and needs of migrants, and on the other hand, opens the field for the implementation of policies in the diaspora.

In general, an effective policy of diaspora management presupposes: the existence of institutions designed to ensure the preservation and development of the diaspora; development of normative legal acts, strategies and programs for managing diaspora processes; interaction of state and non-state actors as a country of residence, and a "titular" state. This will contribute to the creation and strengthening of a stable and comprehensive platform for partnership between the state and the Moldovan diaspora, will ensure the active participation of the diaspora in the sustainable development of the Republic of Moldova.

\section{REFERENCES}

AGUNIAS D.R., NEWLAND K. (2012). Developing a Road Map for Engaging Diasporas in Development. IOM, MPI, 260 p.

Anuarul Statistic al Moldovei (2018). [online]. Available at: http://www. statistica.md/pageview.php?l=ro\&id=2193\&idc=263.

[Accessed 


\subsubsection{9]}

BRINKERHOFF, J.M. (2012). Creating and Enabling Environment for Diaspora's Participation in Homeland Development. In: International Migration, vol. 50, nr.1, pp.75-95.

CHEIANU-ANDREI D. (2013). Mapping of the Moldovan Diaspora in Italy, Portugal, France and the United Kingdom. Chisinau: IOM, 140 p.

DELANO A., GAMLEN A. (2015). Comparing and theorizing state diaspora relations. In: Diasporas Reimagined: Spaces, Practices and Belonging, [online]. Available at: http://www.migration.ox.ac.uk/odp/ Diasporas\%20Reimagined/Diasporas\%20Reimagined_Delano\%20 and\%20Gamlen.pdf [Accessed 17.09.2018].

Global Diaspora and Development Forum. (2014). [online]. Available at: http://www.ucdclinton.ie/GlobalDiasporaandDevelopmentFourm. [Accessed 17.09.2018]

Extended Migration Profile of the Republic of Moldova 2007-2012, (2014). Chisinau, International Organization for Migration, Mission to Moldova, $125 \mathrm{p}$.

Extended Migration Profile of the Republic of Moldova 2008-2013. (2016). [online]. Available at: https://publications.iom.int/books/extendedmigration-profile-republic-moldova-2008-2013 [Accessed 17.09.2018].

Extended Migration Profile of the Republic of Moldova 2009-2014, (2017a). [online]. Available at: https://publications.iom.int/books/extendedmigration-profile-republic-moldova-2009-2014. [Accessed 17.09.2018].

Extended Migration Profile of the Republic of Moldova 2010-2015. (2017b) [online]. Available at: https://publications.iom.int/books/extendedmigration-profile-republic-moldova-2010-2015. [Accessed 17.09.2018]. Hotarirea Guvernului Republicii Moldova nr. 200 din 26 februarie $2016 \mathrm{cu}$ privire la aprobarea Strategiei nationale „Diaspora-2025” si a Planului de actiuni pentru anii 2016-2018 privind implementarea acesteia. Publicat: 04.03.2016 în Monitorul Oficial Nr. 49-54.

KRING T. (2007). Moldovan Migrants in Italy: Remittances and the Role of the ILO's Social Partners. Chisinau, IOM, 2007.

Lista asociatiilor, comunitatilor si grupurilor de initiativă ale diasporei Republicii Moldova. (2016). [online]. Available at: http://brd.gov.md/ ro/content/lista-asociailor-comunitatilor-si-grupurilor-de-iniavaalediasporei-republicii-1 [Accessed 17.09.2018].

MYLONAS H. (2013). The Politics of Diaspora Management in the Republic of Korea. In: The Asan Institute for Policy Studies Issue Brief 81, p.1-12. [online]. Available at: http://www.is.gd/GEHpkQ. [Accessed 25.01.2019] 
MOSNEAGA V. (2014). Republic of Moldova: Diaspora and Diaspora Policy. In: Slovak Journal of Political Sciences, Volume 14, 2014, No. 2, pp.149172.

MOSNEAGA V. (2017). Mapping moldovan diaspora in Germany, UK, Israel, Italy, Portugal and Russia. Chişinău: S. n. 212 p.

MUKOMEL V., CHEIANU-ANDREI D. (2013). Moldovans in Russian Federation: Socio-Economic Profile and Police Challenges. IOM, $112 \mathrm{p}$. SPIRO P.J. (2006). Perfecting political diaspora. In: New York University Law Review, 81(1), p.207-233.

SCHWARTZ R. (2007). Exploring the Link between Moldovan Communities abroad (MCA) and Moldova. Chisinau, IOM, 2007.

The volume of remittances to Moldova through banks in favor of individuals in 2018 amounted to $\$ 1$ billion 266.84 million, an increase of 5.6\% (+ \$ 66.87 million), compared with 2017 (2018). [online]. Available at: http://infomarket.md. [Accessed 25.01.2019]

АНИКИН В. (2016). Выходцы из Молдовы в Израиле: портреты в деловом интерьере и не только. In: MOLDOSCOPIE (Probleme de analiză polică). nr.4 (LXXV), pp.131-154.

Ассоциации молдаван в Российской Федерации. (2016). [online]. Available at: http://www.rusia.mfa.md/oom-russia-ru/. [Accessed 17.09.2018].

МОШНЯГА В. (2013). Становление молдавской диаспоры и миграционная политика Республики Молдова. In: MOLDOSCOPIE (Probleme de analiză politică). nr.4 (LXIII), pp.18-35.

Молдавские мигранты хранят «под подушкой» 6 млрд. евро (2014). [online].Availableat:http://www.ipn.md/ru/economie-business/64135 [Accessed 17.09.2018].

15 приоритетных направлений правительства по работе с диаспорой. (2015). [online]. Available at: http://www.moldovenii.md/ru/news/ view/section/16/id/14898/from/noi. [Accessed 17.09.2018].

ТУРКО Т., СВЕТЛИЧНЫЙ Р. (2015). Разработка и имплементация политики управления диаспорой в Республике Молдова.In: Современные миграционные процессы: состояние и основные формы. Тирасполь, рр. 225-232.

Численность выходцев из Республики Молдова в других странах (2017). [online]. Available at: https://ru.sputnik.md/ infographics/20171230/16423159/naselenie-moldovy-v-mire.html. [Accessed 27.02.2019]. 